\title{
Two grounds of liability
}

\author{
Victor Tadros ${ }^{1}$
}

Accepted: 18 January 2021 / Published online: 5 February 2021

(C) The Author(s) 2021

\begin{abstract}
This essay argues that culpability and responsibility are independent notions, even though some of the same facts make us both responsible and culpable. Responsibility for one's conduct is grounded in the strength of the agential connection between oneself and one's conduct. Culpability for one's conduct is the vices that give rise to that conduct. It then argues that responsibility and culpability for causing a threat are each grounds of liability to defensive harm independent of the other.
\end{abstract}

Keywords Responsibility · War · Self-defence $\cdot$ Liability $\cdot$ Culpability

\section{Introduction}

What makes a person liable to defensive harm to avert a threat? One familiar view is that it is her responsibility for posing or causing that threat, where a person's responsibility is the agential connection between that person and the threat. The paradigm case is choosing to pose or cause the threat, or taking a risk that one's conduct will result in the threat. An extreme version of this view is that responsibility for posing or causing an unjust threat is necessary and sufficient for liability to avert it.

This view is implausible in two ways. First, responsibility for posing a threat is not necessary for liability to avert it. At least some people who are not responsible for causing threats are liable to avert them. They include, for example, those who culpably attempt to pose threats to others. Suppose that two people are wrongly trying to shoot me dead, but one of them has an unloaded gun, and I can make them

Victor Tadros

v.tadros@warwick.ac.uk

1 School of Law, Warwick University, Coventry, UK 
both run away only by shooting the one with the unloaded gun in the leg. The one with the unloaded gun is surely liable to suffer more harm than an innocent bystander would be because she is culpably responsible for trying to shoot me (Tadros 2020 ch.10). Furthermore, fairness sometimes favours liability for those who are not responsible. For example, in a society which depends on a division of labour, it is unfair for all of the costs of wrongful choices to fall on those who make those choices, because that will make some professions much more risky than others with respect to liability to be harmed or killed (Tadros 2020, ch.11). Arguing for any of these alternative grounds of liability is tricky, but it is hard to believe that all such arguments fail.

Second, responsibility for posing or causing unjust threats is not sufficient for liability to avert those threats. Suppose that a person can be responsible for posing or causing a threat by consciously taking a risk of bringing about that threat. Justified risk-takers can then be responsible for posing or causing threats that arise through their justified activities. But at least some justified risk-takers incur no liability through their risk-taking. One clear case is where the evidence-relative justified person acts for the sake of the person threatened, at least if some further conditions obtain. Suppose that $\mathrm{X}$ risks a threat to $\mathrm{Y}$, at significant cost to $\mathrm{X}$, in order to avert a greater threat to $\mathrm{Y}$; $\mathrm{Y}$ will be much better off than $\mathrm{X}$ whatever happens; and although $\mathrm{Y}$ is unable to consent to be harmed, $\mathrm{Y}$ would consent were he able. $\mathrm{X}$ is not liable to avert the threat to $\mathrm{Y}$ if things go bad.

Perhaps it might be argued that $\mathrm{X}$ is not responsible for the threat in that case. Jeff McMahan's influential view that responsibility grounds liability relies on a thin notion of responsibility, where conscious risk-taking is sufficient for responsibility for threats that arise through that risk-taking, and the risk-taker described in the previous paragraph is responsible on that view (McMahan 2005). ${ }^{1}$ This view might be rejected in favour of a narrower conception of responsibility-one tied to blameworthiness, for example. If this narrower conception is adopted, the view under consideration is then just the view that culpability, or culpable responsibility, makes people liable to avert threats, where culpability depends on the moral quality of the agential connection between a person and her conduct. That moral quality, I will suggest, is determined by the virtues and vices that characterise that agential connection. Acting on, or with, the relevant vices makes one blameworthy. Fully explicating this account would involve an investigation of what acting on a vice amounts to. But my arguments don't depend on any particular view about that, so I won't pursue that issue further here.

An extreme version of that view is that culpability is necessary and sufficient for liability. That view implies that culpable attempters are liable to avert threats, but not those who justifiably take risks for the sake of others. But culpability is not necessary for liability. At least some people who are responsible but not culpable are liable to avert the threats they pose or cause. For example, well-off people are sometimes justified in risking harm to those who are worse off than them, even

\footnotetext{
${ }_{1}$ Many others think that at least some kinds of risk taking of this kind grounds liability, even without culpability. For example, Jonathan Quong thinks this is true where the person takes a justified risk about whether the person she attacks lacks rights (Quong 2012).
} 
where the risk-imposing conduct benefits the well-off people themselves. But these people are liable to incur costs to avert threats to those who are worse off than them when things go bad. For example, my owning a dog may be permitted, even though there is some tiny risk that the dog will attack my neighbour. But if the dog does attack the neighbour, I have to bear costs to prevent the neighbour from being harmed. That is part of the price of my owning the dog. This suggests that blameworthiness is not necessary for liability.

And culpability is not sufficient for liability. A person who lies to her spouse does not become liable to avert unrelated threats of harm that others face. Even if responsibility for posing or causing a threat is not always necessary for liability, which must be true if attempters are liable to avert threats posed by others, there must be some connection between the person's culpability and the threat to make the person liable.

These initial remarks already suggest that there is no simple principle that captures the full grounds of liability. Culpability and responsibility are sometimes independently sufficient for liability to defensive harm. My aim here is to develop this idea further by exploring the relationship between responsibility and culpability, and the way in which these things ground liability. How are responsibility and culpability distinguished and related? How are they related as grounds of liability? And how does the magnitude of a person's culpability or responsibility relate to the magnitude of her liability?

\section{Scalar liability}

A person is liable to be harmed if she lacks a right not to be harmed. ${ }^{2}$ As people normally have at least pro tanto rights not to be harmed, at least if the harm is significant, we typically need an explanation why a person lacks such a right. Culpability and responsibility for posing threats are plausible grounds of liability that may be offered as explanations why a person who would normally have rights not to be harmed lack those rights in particular cases.

Here is a simple general view of the relationship between the grounds of liability and the magnitude of liability. Suppose that some ground of liability is a scalar thing. As the magnitude of the ground increases, the magnitude of liability proportionally increases. For example, suppose that responsibility for causing a threat is a ground of liability to defensive harm, and responsibility is a scalar notion (which it surely is). The simple view just described is that a responsible person's liability is in proportion to her responsibility for causing the threat.

I doubt that things are so simple. There are some grounds of liability that are scalar, but that don't affect liability in a scalar way. For example, suppose that causing a threat is a ground of liability (either on its own, or conjunction with something else, such as responsibility or culpability). The degree of a person's

\footnotetext{
2 This is a relatively broad conception of liability compared with those focused only on those who lose rights, or who forfeit them. I defend the view that it is the best conception in Tadros (2016).
} 
causal contribution to a threat may be scalar, but there are doubts about the view that liability is related to this scale (Tadros 2018; Beebee and Kaiserman forthcoming; Sartorio forthcoming).

Still, at least some of the grounds of liability are scalar, and have a scalar impact on liability as we will see. Thus, we should get clear on the ways in which liability is scalar. To understand one way, consider this simple case:

Simple Threat: A threat to Victim can be averted only by harming Xavier to a certain degree $n$.

The magnitude of Xavier's liability to be harmed to avert the threat is the magnitude of harm that can be inflicted on Xavier without wronging him. Let's call that magnitude $l$. If $n<l$, Xavier will not be wronged if he is harmed to avert the threat to Victim; if $n>l$, he will be wronged. There is a further set of questions whether Xavier is wronged if unnecessary harm is inflicted to avert the threat to Victim where the harm inflicted on him is $<l$. If so, we should say that $l$ equals the maximum amount of harm that could be inflicted on Xavier without wronging him were there no other way to avert the threat. I leave aside the relationship between necessity and liability. ${ }^{3}$ Let's call the kind of liability we are discussing here individual liability. And let's call $l$ Xavier's individual liability threshold.

In other cases, whether harming a person to avert a threat wrongs her depends on the fair distribution of harm between that person and others. In such cases, selecting a person to be harmed may wrong her because another person ought to be selected instead, or because too much harm is allocated to her rather than others. This can occur where the harm inflicted on her is below her individual liability threshold.

Consider:

Choice: Harming one of two people, Alice and Betty, to a certain degree, $n$, is the only way to avert a threat to Victim. To avert the threat, $n$ harm must be allocated either to Alice or Betty and cannot be divided between them. Other than things that make them liable to avert the threat, other things are equal between Alice and Betty.

Let us suppose that responsibility is scalar, responsibility makes people liable on a scalar basis, and Alice is more deeply responsible for causing the threat than Betty. Let us also suppose that $n$ is less than the individual liability threshold of both Alice and Betty. Betty is wronged if she is harmed to avert the threat even though she would not have been wronged had harming her to that degree been the only way of averting the threat, say because the threat could not have been averted by harming Alice. Thus, Betty is wronged because the harm ought to have been inflicted on Alice rather than her. We can call this kind of liability selective liability. Although Betty is individually liable to be harmed to degree $n$ to avert the threat to Victim, she is not selectively liable to be harmed to avert that threat, and thus harming her to

\footnotetext{
3 For different views, see for example McMahan (2009, 8-9); Quong and Firth (2012), Frowe (2014, ch.4) Tadros (2020, ch.8).
} 
avert it wrongs her. Alice, in contrast, is both individually and selectively liable to avert the threat, and thus she is not wronged at all if she is harmed to avert it.

Difficult questions arise about the implications of wronging a person, or attempting to wrong a person, where that person is individually but not selectively liable. I cannot fully answer those questions here. Suppose, for example, that I wrongly harm Betty, where I ought to harm Alice because although Betty is individually liable to be harmed, Alice is selectively liable to be harmed. Is Betty owed compensation, and by whom? I find it clear that Alice owes Betty compensation, because the harm ought to have been allocated to Alice in the first place. But suppose that Alice cannot be made to pay. Do I then owe Betty compensation? I think that I might, though perhaps my duty to pay is not very stringent. Similarly, if I am about to harm Betty rather than Alice, Betty is permitted to divert the harm to Alice. Is she also permitted to divert the harm to me because I have wronged her? That depends a range of considerations, some of which I consider below, but I think I might be required at least to share some of the harm with her, given my wrongdoing.

Individual and selective liability are obviously related, or at least their grounds are normally the same: the things that increase a person's individual liability threshold tend to make her selectively liable, so that there are stronger reasons to select her rather than others to be harmed to avert the threat. We can then just use the crude umbrella phrase 'magnitude of liability' to refer to both kinds of liability.

But although they have similar grounds, selective liability is especially helpful in exploring our judgements about the grounds of liability, because the individual liability threshold is often unclear. The degree of harm that it is proportionate to inflict on a person to avert a threat is vague or indeterminate. It is then difficult to tell whether a factor increases or decreases the individual liability threshold. To test whether some factor increases the magnitude of liability, it is often better to focus on cases where selective liability is at issue. In such cases, even if the individual liability threshold is unclear, it is often clear who is selectively liable.

\section{The quality of the threat}

The magnitude of a person's liability to avert a threat obviously depends on the gravity of the threat. When assessing the significance of responsibility and culpability for liability, we must be careful to hold constant the gravity of the threat as far as possible. This is not always easy, as culpability and the gravity of a threat often go together: it is normally more culpable to pose or cause a graver threat. But, of course, the culpable person may not be aware of the magnitude of the threat she causes, and so culpability and the magnitude of the threat can also come apart.

Many things affect the gravity of threats. I won't offer a complete account here. The most obvious factor is the amount of harm that will be inflicted on the victim if the threat is not averted. But that is not the only relevant factor. At least one possible factor makes it impossible to keep culpability and gravity fully apart: culpability may affect the gravity of the threat as such. Consider the familiar, but contested, view that we have stronger reason to rescue a person from injustice than from 
natural disaster. ${ }^{4}$ One way to understand this view is that it is worse for a person to be the victim of injustice than natural disaster, and this gives the potential victim of injustice a stronger claim to be saved. Now compare a person who is highly culpable for posing a threat and a person who is either evidence-relative permitted, or merely negligent, in posing a threat of a similar magnitude of harm to another person. It might be argued that the former bears more liability than the latter because she is responsible for posing a graver threat - graver because it is more culpably posed. Even in this case, though, we could assess the significance of culpability independently of the gravity of the threat. We could do so by considering who is more liable to avert a single threat to a victim that is caused by one person acting in a seriously culpable way, where the other is merely negligent.

The gravity of the distributive injustice that a person will suffer if she is harmed may also ground liability independently of the magnitude of harm threatened. Consider prioritarianism-the plausible view that the justice of diminutions and improvements in a person's welfare depends not only on the magnitude of these diminutions and improvements, but also on how well off or badly off the person will be left overall (Parfit 2002). ${ }^{5}$ On that view, the strength of the reason to avert a threat that someone faces depends not only on the magnitude of the harm that the threat will cause, but also on how well off or badly off the person will be left if the threat is not averted. And a natural further implication is that those who pose threats of harm to those who will be left worse off are liable to suffer greater harm than those who pose threats of harm to those who will be left better off, where harm is held constant.

This may also seem to be a view about culpability - threatening a worse off person might seem more culpable than threatening a better off person. But it is not. It is concerned with the effects of the person's conduct, rather than the state of mind that leads to those effects. One illustration of this idea draws on the fact that posing or causing the threat might be evidence-relative permissible, and yet the person posing or causing it may be liable to avert it. For example, suppose that Xavier is evidence-relative permitted to inflict a risk of harm on Victim. Things go bad, and Victim is now threatened with harm, but Xavier can be harmed to avert that threat. If prioritarianism is right, and permissible risk imposition can ground liability (as I have argued that it can), the magnitude of Xavier's liability depends on how badlyoff Victim will be if she is harmed.

Let us then say that one set of facts that affects liability is the gravity of the threat, where the gravity of a threat is not just the magnitude of harm that will be inflicted on the victim if the threat is not averted, but the range of considerations that determine how bad or unjust it will be that the victim is harmed if the threat is not averted.

In addition to the gravity of the threat, there may be factors that are independent both of the liable person and the gravity of the threat that affect liability. For

\footnotetext{
${ }^{4}$ For different views, see Scanlon (1998, 258), McMahan (2010), Singer (2010), Tadros (2011, ch.5) and (2016, ch.9), Parfit (2017, 400-406).

5 Though Parfit doesn't formulate prioritarianism in quite this way, this is the more general version of the view.
} 
example, the magnitude of a person's liability to avert a threat may depend on the extent to which the victim was responsible for being threatened, or on her opportunity to avoid being threatened. But the fact that a person will be responsible for bearing a cost, or could have avoided it, need not make a threat that she faces any less grave. Suppose that I negligently drive a digger on a building site. The digger goes out of control, and a bystander is threatened. If the bystander could have avoided being threatened by heeding warnings not to go on the site, my liability to be harmed to avert the threat might be reduced, perhaps because the bystander will be responsible for any harm she suffers, or because she could have avoided suffering the harm simply by heeding the warnings. ${ }^{6}$

We can thus see that several factors affect a person's liability to defensive harm. These include that person's culpability and responsibility, the gravity of the threat, but also considerations about the victim that do not affect the gravity of the threat, such as her own responsibility for any harm that she suffered, or her opportunity to avoid it. We are concerned only with the first two factors.

\section{Excuses}

Our question is what bearing culpability and responsibility have on liability. I have already mentioned the very difficult question whether the extent to which a person is responsible for posing or causing a threat, or is liable to avert it, depends on the magnitude of her causal contribution to it. That question is too difficult to answer here, so let us set it aside. What other features of responsibility and culpability might make a difference?

Let us begin with the familiar view that the magnitude of a person's liability to be harmed depends on whether she is partially excused for the threat she causes. Jeff McMahan argues that excuses make a difference to liability (McMahan 2009, ch.3). ${ }^{7}$ Jonathan Quong, in contrast, claims that a person's liability depends on the stringency of the rights that she threatens to infringe or violate. The degree to which she is responsible or culpable for violating rights of the relevant stringency, which is what excuses are concerned with, does not affect liability (Quong 2015). ${ }^{8}$

Quong defends his view in part by appealing to the intuition that the magnitude of harm that may permissibly be inflicted on a person who is about to commit an assault does not depend, for example, on whether he has had his drink spiked by his friends (Quong 2015, 153). This case, though, is hard to evaluate. If the intoxication is not very severe, the excuse that arises through having one's drink spiked may well be quite weak, and, as I noted earlier, we do not have precise intuitions about the individual liability threshold.

\footnotetext{
6 The best version of this idea is subject to significant debate. See, for example Scanlon (1998, ch.6), Williams (2007), Stemplowska (2013), Tadros (2020).

7 See, for example,

8 See.
} 
When we focus on cases where the excuse is more profound, and selective liability is at issue, we see that McMahan has the right view. Consider:

Duress: If Xavier and Yolanda each press a button, a missile will be launched at five innocent people, and they are both about to press. Everything is equal between Xavier and Yolanda, except that Zelda has a gun to Yolanda's head and is screaming at her to press, threatening that she will shoot her if she does not. Terrified, and to prevent herself from being killed, Yolanda is about to press. Xavier, in contrast, simply hates the five, and he is also about to press. I can avert the threat only by harming either Xavier or Yolanda to degree $n$ where $n$ is below the individual liability threshold of either Xavier or Yolanda.

Here is an argument against Quong's view. Xavier and Yolanda threaten to violate an identical right. They therefore threaten to violate a right of identical stringency. Quong's view thus implies that their magnitude of liability is identical. Now suppose that I am right that the facts that affect selective liability also affect individual liability. In conjunction with Quong's view, this implies that there is no difference in the selective liability of Xavier and Yolanda. But Xavier is clearly liable to be killed. On this view, then, I don't wrong Yolanda if I kill her rather than Xavier. As far as their rights are concerned at least, Quong's view implies either that I may pick either Xavier or Yolanda, or that I must flip a coin. This view is hard to believe. Surely, I wrong Yolanda if I pick her, either directly, or as a result of her losing a coin flip. Either she is not individually liable to be killed, or even if she is, Xavier is selectively liable to be killed. Therefore, Quong's view must be rejected.

Perhaps Quong might argue that there is a difference in the stringency of the rights that Xavier and Yolanda will violate. He believes that the stringency of a right depends in part on the mode of agency that is involved. A person has a stronger right against being used, for example, than she does against being harmed as a side-effect. Xavier intends to kill the five (Quong 2015, 160) But, it might be argued, Yolanda only does so as a side-effect of her intention to press the button.

To remove this feature, we might suppose that rather than hating the five, Xavier is offered $£ 500$ to press his button. However, he knows that in doing so he will kill the five, if Yolanda presses her button as well. Both are about to press. It is still clear that Xavier is selectively liable to be killed, and that I would wrong Yolanda by killing her.

Perhaps Quong might argue that Yolanda is justified in pressing the button, and thus she does not violate the rights of the five. ${ }^{9}$ But it is normally wrong to kill five people to save one's own life. Furthermore, we might reduce the magnitude of the threat that Yolanda faces from Zelda. Let Zelda threaten to cut off one of Yolanda's fingers. Now she is clearly not justified in killing the five on any plausible view. Yet it is still clear that Xavier rather than Yolanda is selectively liable. This suggests that Quong is wrong to think that neither culpability nor responsibility is relevant to

\footnotetext{
9 Some argue that excuses themselves are operative only if they vitiate moral obligations. See, for example, Wallace (1994). For a powerful argument against this view, see Sliwa (2019).
} 
liability. Duress, in this case, partially excuses Yolanda from pressing, and that limits her liability to be harmed. ${ }^{10}$

But whilst this case tells decisively against Quong's view, it does not tell us what it is about duress that affects liability. Here are three ideas. On one view of excuses-the reasons view-a person is excused because although she acted wrongly she acted on good reasons, or reasons that are at least understandable or not too bad, compared with those who are not excused (Gardner 2007a, b). On another view-the ability view - a person is excused because her ability to reason was interfered with. On a third view-the character view-a person is excused because although she acted wrongly, her wrongful action did not reflect her bad character. And there may be other views.

A further and more general view is that there are different kinds of excuse, and none of the views outlined captures all of them (Tadros 2005 chs. 11 and 12). ${ }^{11}$ Whether this view is right depends in part on the verbal question how we carve up the moral territory between excuses and denials of responsibility. Some think that some denials of responsibility count as excuses and others do not. For example, some think that serious mental disorder excuses, where others think that it impacts on responsibility in a way that makes a person non-responsible, and thus she does not need an excuse for what she does. ${ }^{12}$

Whatever the best way to carve excuses and responsibility, though, if Zelda's duress interferes with Yolanda's ability to reason, causing Yolanda to reason incorrectly, Yolanda's liability is diminished as a result. And that is sufficient to explain why Xavier rather than Yolanda ought to be harmed to avert the threat. The force of this idea is clear in cases where a third party affects a person's reasoning ability without affecting her reasons for action:

Involuntary Intoxication: Xena and Yoshi each attempt to push Victim's car into the river. Everything is equal between Xena and Yoshi, except that Zelda heavily involuntarily intoxicated Yoshi, and that is why he decides to join Xena in pushing the car. He does not normally get intoxicated, precisely because he knows that this badly affects his judgement. Xena is not intoxicated. But Xena and Yoshi act for the same reason - they think it will be funny to see Victim's nice new car destroyed. I can avert the threat only by harming either Xena or Yoshi to degree $n$, which is below the individual liability threshold for either.

I should harm Xena rather than Yoshi, but they act for the same reasons. This suggests that interference with a person's reasoning capacity that causes him to act for bad reasons affects liability independently of the quality of the person's reasons

\footnotetext{
${ }^{10}$ A further view is that desert rather than liability explains why I must harm Xavier. I argue against this view below.

11 See. For a recent attempt at a more uniform view, see Sliwa (2019). Sliwa thinks that all excuses involve those whose good intentions are blocked, leading them to act wrongly. I doubt this could be right, though, partly because a person might be excused for lacking good intentions in the first place, say because she is brainwashed into forming bad intentions.

12 I think that this is Gardner's view in (2007a) and (2007b).
} 
for action. If a person acts for bad reasons because his reasoning capacity is interfered with, his liability is reduced. Whether involuntary intoxication should count as an excuse or a denial of responsibility is a terminological question that we can set aside.

This leaves unanswered the question whether the fact that Yolanda acted for better reasons than Xavier in Duress makes Yolanda less liable than Xavier to avert the threat. I argue below that it does. If this is right, duress has more than one role to play in affecting liability-it can reduce a person's liability both by affecting her ability to reason, and by affecting the quality of the reasons for which she acts.

\section{Culpability and responsibility}

So far, I have argued that excuses affect liability without distinguishing very clearly between culpability and responsibility.

\subsection{The basic view}

Here is a very brief sketch of the distinction between culpability and responsibility, as I will understand it. A person is responsible for some wrongful conduct because of the strength of the agential connection between the person and that conduct. A person is culpable for some wrongful conduct, in contrast, because of the bad moral quality of that agential connection, where the moral quality of the agential connection depends on the extent to which it is caused in the right way by virtues or vices.

Let me make a quick comment about this last idea. Some might be tempted by the view that culpability is a matter of the quality of the reasons that a person acts for, rather than her virtues and vices more broadly. But whilst acting for bad reasons is a central case of culpability, it is not the only case. A person might be culpable for acting because she fails to be motivated by certain decisive reasons against acting, even where she acts for good reasons. And a person might act for good reasons, but be culpable because, due to a vice such as obliviousness, she fails to notice decisive reasons against acting. The qualification 'in the right way' is added at the end of the previous paragraph to avoid false attributions of culpability in cases where there are unusual causal chains between a person's vices and her wrongful conduct.

On this view of the distinction between culpability and responsibility, a person's responsibility for conduct is not grounded in, or otherwise strongly tied, to the aptness of certain responses, such as blame or resentment, to the person because of her conduct. The aptness of responding to a person in a certain way depends not only on the strength of her agential connection to conduct, but also on the virtues and vices that caused that conduct; it is a matter of culpability as well as responsibility. The view under consideration, then, is that a person can be fully responsible for conduct even though no particular response to her conduct is apt. This is so where the act in question is morally neutral.

Although this view is controversial, it is also appealing. To see this, note that committed assertions about responsibility do not depend on committed assertions 
about the moral quality of a person's conduct. If I say in an appropriate and committed way: 'X was responsible for ving', I neither imply a negative nor a positive assessment of X's ving. Which assessment is intended, if either, depends on my attitudes about ving.

Consider:

(1) Xander was responsible for preventing Yael from harming Zach.

A person who claims this, and does so appropriately and with commitment, need not imply anything either negative or positive about Xander's harming Zach. What is implied depends on the person's beliefs about the moral properties of Xander preventing Yael from harming Zach, and that depends on the person's assessment of the moral properties of Zander harming Zach. To see this, compare:

(2) Xander was responsible for preventing Yael from justifiably defending herself against Zach by harming her.

(3) Xander was responsible for preventing Yael from wrongly harming Zach.

We do not need to know whether (2) or (3) is true to know that (1) is true. This suggests that responsibility does not depend on the moral quality of a person's conduct.

Some might respond that there are at least two senses of responsibility-positive and negative responsibility. 'Responsible' means 'positively responsible' in (2) whereas it means 'negatively responsible' in (3). On this view, we need more information about (1) to determine which sense of responsibility is being used.

This, though, is false. Suppose that I know that either (2) or (3) is true, but I don't know which. I nevertheless know that Xander was responsible for preventing Yael from harming Zach. This suggests that there is a single sense of responsibility that I can know Xavier has if (1) is true, even if I don't know whether (2) or (3) is true. This, I suggest, is also the sense of responsibility that is used in (2) or (3).

To reinforce this view, consider:

\section{Conversation:}

You: someone prevented Yael from harming Zach. Whom is responsible for doing that?

Me: Xander was responsible.

You: Given that, he deserves praise.

Me: No, Yael was justifiably acting in self-defence. So, because he was responsible, he deserves blame.

In this apt conversation, we rely on a single sense of responsibility that does not determine whether praise or blame is involved. This suggests that there is one sense of responsibility for preventing Yael from harming Zach, where Xander's responsibility partly grounds the aptness of blaming him if his conduct is wrong, but partly grounds the aptness of praising him if his conduct is good. ${ }^{13}$ The

$\overline{13}$ Compare, for example, Scanlon (1998, 248), Smith (2007, 467-468). 
additional grounds are the virtues and vices that cause his conduct and the moral quality of the conduct itself.

Conclusions about responsibility are secure in the absence of information about the quality of a person's reasons for action because the quality of the reasons why a person acted need not have any bearing on the strength of the agential relationship between a person and her conduct. Given that Xander is agentially connected to his conduct in the right way, we can conclude that Xander is responsible for what he did, regardless of the quality of his reason for action.

The appropriate agential connection between a person and her conduct is a necessary condition (or, perhaps, precondition) of the appropriateness of certain responses, such as blame. We don't blame a person for conduct that she is not agentially connected to. Thus, the view I have sketched is compatible with some kind of response-dependent view of responsibility: a person is responsible, it might be claimed, in virtue of the fact that she fulfils one ground of the aptness of certain responses such as praise or blame. ${ }^{14}$

\subsection{How responsibility bears on culpability}

Spelling out what makes the agential connection between a person and her conduct stronger or weaker is a complex question that I cannot address here. In cases such as Involuntary Intoxication, involuntary intoxication presumably bears on Yoshi's responsibility on any sensible view. The agential connection between Yoshi and his conduct is weakened by the fact that his reasoning capacity is diminished, and he is not responsible for the diminution in that capacity.

Some might doubt the view that responsibility and culpability are distinct because that may seem to imply that Xena and Yoshi are equally culpable in Involuntary Intoxication. This may be thought to follow because they each act for identical reasons. But this view also seems implausible-surely Yoshi is less culpable as well as less responsible for damaging the car.

One response draws on a remark I made earlier: culpability is not a matter simply of the quality of the reasons for which one acts. It depends on the extent to which one's responsible conduct manifests virtues and vices. Because Yoshi's reasoning capacity is interfered with, his conduct does not fully manifest the vice of poor judgement. Another response is that when we assess whether someone is culpable because of the reasons for which they act, we should assess both the quality of the reason that motivated the action, and also the extent to which that reason is attribute to the person who acted. Although Xena and Yoshi acted for identical reasons, that reason was less deeply attributable to Yoshi than Xena. This view suggests that a person's responsibility does bear on her culpability in this way. The fact that a person is less strongly connected to the reasons that motivate her action can make her less culpable for her action. Whilst I am tempted by this latter view, I do not rely on it here.

\footnotetext{
$\overline{14}$ I do not, myself, believe that such a view is right for other reasons.
} 
We might also conclude that cases such as Involuntary Intoxication don't establish that the degree to which a person is responsible for her conduct affects the magnitude of her liability to defensive harm independent of her culpability. But we have already seen that responsibility is a ground of liability independently of culpability - at least in some cases, a person can be liable to be harmed to avert threats that she brings about through voluntary permissible risk-taking. And if the risk-taking is permissible, there is normally no question of the person being culpable.

Can the degree to which a person is responsible for permissible risk-taking affect her liability? It can. Suppose that $\mathrm{X}$ is well-off. She has an option to make herself better off by ving, but ving comes with a small risk that $\mathrm{Y}$ will be harmed. $\mathrm{Y}$ is worse off than $\mathrm{X}$, but the risk is small enough for ving to be permissible. Now suppose that $\mathrm{X} v \mathrm{~s}$. The extent to which $\mathrm{X}$ is liable depends on the extent to which $\mathrm{X}$ is responsible for choosing to $v$. For example, suppose that $\mathrm{X}$ is heavily involuntarily intoxicated, and for that reason chooses to $v$. Without the intoxication, $\mathrm{X}$ would have been more risk averse, and so would not have ved. The intoxication seems to have at least some bearing on the magnitude of X's liability to avert the threat that she faces.

Again, we can see this in cases of selective liability. Consider:

Supercars: Johann and Karl are multimillionaires. They each own a supercar, with an automated driving system and Johann suggests that they race. There is a tiny chance, if they do this, that they will cause a landslide, which will kill Vlad, who lives in the valley near the track. But the risk is so small that racing the cars is permissible. Karl is much more risk averse than Johann, and doesn't want to race. Larry wants to see them race, and so intoxicates Karl without his knowledge. As a result, he agrees to race, and they do so, both sitting in the back of their cars. Due to an imperceptible fault in a nearby rock formation, a landslide is about to start, which will kill Vlad. This can be stopped only by my shooting one of the two cars. But this will cause that car to crash, risking serious injury to the passenger in that car. The other passenger will be unharmed.

The view that Johann and Karl are individually liable to be harmed to avert the threat to Vlad is highly appealing. Neither is culpable, I have stipulated. Johann is more deeply responsible for the risk that he imposes on Vlad than Karl, whose responsibility is diminished due to involuntary intoxication. Because of that, Johann is selectively liable, and Karl is wronged if his car is shot rather than Karl's. This suggests that the magnitude of a person's responsibility for posing a threat can ground liability independently of culpability.

\section{Culpability as an independent ground of liability}

So far, we seen that responsibility affects liability. Some excuses, such as involuntary intoxication, affect responsibility and that has a direct bearing on liability, whether or not the diminution of responsibility impacts on the person's 
culpability. Is the converse also true? Is liability grounded in culpability independently of responsibility? It is.

Culpability and responsibility are often not clearly separated in discussions of liability to defensive harm. One reason, I think, is that at least some of the facts that make people more culpable make them more responsible. Any scale of responsibility or culpability is controversial, but consider the standard mens rea categories that we find in criminal law:

(a) intending harm,

(b) foreseeing harm as certain,

(c) reckless harm, and

(d) negligent harm.

It seems plausible that, other things equal, there is a scale of culpability from (a) to (d), and a scale of responsibility for harm from (a) to (d). The very same facts - a difference between intending harm and merely foreseeing harm as certain, for example, thus make a difference to both culpability and responsibility.

Some might doubt this. To assess it, consider:

Doctors: Two doctors, Ed and Fred, are involved in a blood transfusion for Victim. They both act identically except for their mental state - both give several pints of blood to Victim. The blood is infected and Victim dies.

First, suppose that Ed intends to kill the victim, whereas Fred is merely negligent. Ed knows that the blood is infected, and that is why he gives it to Victim. Fred, in contrast, fails to perform adequate checks on the blood that he gives. It is clear, to me at least, that Ed is more responsible for the death than Fred, and not merely more culpable.

Things are less clear where the mental states are more closely related. Suppose, for example, that Ed intends to kill Victim. Fred, in contrast, knows that he is giving Victim infected blood. He just does this because he's in a hurry to get home, and it would take time to find non-infected blood. Again, I think that Ed is more responsible for the death than Fred. But my intuitions are less clear.

Here is an explanation of these differences that does not depend on the idea that differences in culpability affect differences in responsibility. The degree of a person's responsibility for harm, I have suggested, is constituted by the strength of the agential connection between that person and the harm. The agential connection between the person and the harm is scalar, where intending is the strongest of the four connections above, and negligence is the weakest. Here is why the agential connection between a person and harm is stronger if the harm is intended. One central fact that is of distinctive and central importance in human agency is the ability to plan our conduct over the course of our lives in the light of what we value. And there is a deep relationship between intending and planning. ${ }^{15}$ The agential connection is also strong, though, in cases where we know what our conduct will

\footnotetext{
15 The work of Michael Bratman, over many years, has been central to exploring this connection, going back to his influential Bratman (1999).
} 
bring about, and we either act despite its occurrence, or fail to respond to it. It is weaker in cases where we are either uncertain whether the fact will come about, or where we are unaware of that occurrence due to epistemic failure. Thus, a person is more deeply responsible for the harm that she intentionally causes than the harm that she merely foresees, and she is more deeply responsible for the harm that she foresees as certain than the harm that she brings about recklessly or negligently.

But it is also typically more culpable to intend harm than to merely foresee it. Exactly why is a matter of dispute. It may be because harming a person as a means or an end involves setting one's will towards something where it is appropriate to be adverse to it, or because intending harm often amounts to using a person, ${ }^{16}$ or for some other reason. It is relatively uncontroversial that it is worse knowingly to bring about harm without justification than to take a risk, and that the higher the magnitude of the risk the more culpable a person is. And knowingly risking harm is more culpable than bringing it about negligently. Thus, several of the central facts that make a person more responsible also make her more culpable.

But, I have argued, some of the things that make a person more culpable for harming a person do not make her more responsible. For example, culpability depends on the quality of a person's motivations harming another person, but the quality of her motivations do not make her more or less responsible. To assess the bearing of culpability on liability, independently of responsibility, there are two kinds of case to consider. In the first, there is good reason to inflict harm on a person. But that reason is insufficient to justify doing so. A person might inflict harm for that good but insufficient reason. Or she may do so for some bad reason. The reason why the person inflicts the harm does not affect her responsibility for causing a threat, but it does affect her culpability. And it affects liability.

Consider:

Two Pushers A trolley is heading towards five people. The five can be saved only by pushing Victim off a bridge in front of the trolley. Cara and Delphine can push Victim only if they do so together. They are both about to push. Cara will act in order to save the five, regretting killing Victim. Delphine does not care for the five, but hates Victim, so will push only in order to kill him. I can prevent Victim from being pushed only by harming either Cara or Delphine below the individual liability threshold.

Suppose that it is wrong to push Victim off the bridge. Cara and Delphine will each act wrongly if they push and will be culpably responsible for Victim's death if nothing is done. But Cara will kill for a good, but insufficient reason-the saving of the five. Delphine will kill for a bad reason.

The different reasons for which they will act have no bearing on the responsibility they will have for killing Victim. This is the intuitive view, and it is explained by the distinction that I offered earlier between culpability and responsibility: the strength of the agential connection between their conduct and the

\footnotetext{
16 There is a large literature on both ideas. For the former, see, for example, Nagel (1986 180-5); for the latter Quinn (1993).
} 
killing is not affected by the quality of the reason for which they act. And this also supports the view that I offered earlier that responsibility and blameworthiness are distinct-Delphine will be more blameworthy than Cara for the killing, but not more responsible. Nevertheless, intuition supports the view that I should harm Delphine.

In the second kind of case two people act for bad reasons, but one person's reasons are worse. Again, the quality of the reasons affects culpability, not responsibility, but also affects liability. Consider:

Two Killers: Xavi and Yahir are beating Vaughan, a black person, and will kill him if nothing is done. Xavi does this just to rob Vaughan, where Yahir does it both to rob him and also from deeply racist motives. I can prevent Vaughan's death only by harming either Xavi or Yahir below the individual liability threshold. If I do this, the other will run off.

Yahir is more culpable than Xavi because his motivations are worse. But they are equally responsible for the threat they pose, and they will be equally responsible for the death if nothing is done. Intuitively, I ought to harm Yahir rather than Xavi.

Before getting to my positive case that culpability affects liability, let me explore an alternative explanation of these intuitive judgments. It might be argued that although there is no difference in liability between those who are more culpable and those who are less culpable, there is a difference in how bad it is that that a person is harmed that depends on culpability, and that determines what I ought to do. The most prominent version of the view that it is less bad that the culpable suffer is based on desert. ${ }^{17}$

One reason to reject this view is that it is not less bad that more culpable wrongdoers are harmed when compared with less culpable wrongdoers. I don't find such views plausible in general for reasons that I cannot explore here (Tadros 2011, ch.4). Furthermore, the most plausible versions of desert-based views do not have culpability as the desert-base, but rather character or disposition over the course of a life. And what is deserved is not some particular kind of harm, but rather a level of well-being over the course of a life. ${ }^{18}$ Yet it is not very plausible that I generally ought to harm those who have worse dispositions or character than those who have better dispositions or character in particular cases of defensive harm. Suppose that Vaughan is white, and that Xavi and Yahir therefore act for the same reasons. However, as Yahir is a racist, he would also have acted for racist motives had Vaughan been black. Yahir is no more culpable for killing Vaughan than Xavi in this variation. He is, however, a worse person, and would act on worse motivations in nearby possible worlds. But his character and dispositions are irrelevant to his liability to be harmed. There may be reasons to harm him rather than Xavi if he is

\footnotetext{
17 The view that desert has an important role to play in the ethics of defensive harm is a distinctly minority view. However, for a defence, see Gardner and Tanguay-Renaud (2011). Recently Jonathan Quong also argues that we select between culpable and non-culpable people on the basis of desert, other things equal. See Quong (2020, 46-47).

18 This is, for example, Shelly Kagan's preferred view. See Shelly Kagan's (2012, 6-8).
} 
more likely to pose greater threats in the future. But his character and disposition do not justify harming him in themselves.

And it is not very plausible that the reason why I ought to harm the more culpable person in Two Pushers and Two Killers is to ensure that their level of well-being is deserved over the course of their lives. I ought to harm Yahir in Two Killers, for example, even if Yahir is already worse off than Xavi with respect to well-being.

In order to vindicate our intuitions about defensive harm, then, any desert-based view must be much more local both with respect to the desert-base and what is deserved. But such local versions of desert are even harder to defend than more global variations (Tadros 2011, ch.4).

Furthermore, the view that I ought to harm the more culpable person without appealing to liability is quite generally hard to defend. Suppose that it is less bad that culpable people are harmed. This does not affect what I ought to do if it makes no difference to the rights of the culpable or the non-culpable. If culpability does not weaken the rights of the culpable, the culpable have equal rights not to be harmed as the non-culpable. Responding appropriately to these rights, then, requires me to give the culpable and the non-culpable equal chances of being harmed, even if harming the culpable is less axiologically bad. Just as I do not gain rights to things simply because it is better that I have them, I do not lose protective rights simply because it is less bad that I am not protected. ${ }^{19}$

We are better, then, to seek explanations of our intuitions in the cases we are now considering that are more closely tailored to the features of those cases - differences in culpability concerning the harmful wrongdoing that will be prevented by harming the person. And we are better to seek an explanation why the rights that people have are weakened by their culpability.

Here is a sketch of such an account, which I cannot fully develop here. A person's rights not to be harmed to avert threats they pose are closely related to the duties they have to avert those threats (or that they would have were they able to avert those threats). The more stringent a person's duty to avert a threat that she poses, the weaker her right not to be harmed to avert that threat. ${ }^{20}$

If that basic idea is right, does culpability affect the strength of a person's duty to avert a threat she poses? Here is why it does. A person has especially strong reasons to ensure that her own moral faults are not the source of threats to others, and where they are to ensure that those threats are not realized. For it should be a source of deep disquiet for her that her culpable decision-making issues in harm to others. That deeply problematic connection between her and the suffering of others that her culpability will give rise to makes her duty to avert threats that she culpably poses especially stringent.

Perhaps some might argue, in response, that the strength of a person's duty to avert a threat does not depend on culpability in particular, but just on her being the source of the threat, or just on her having certain properties, such as dangerousness,

\footnotetext{
19 This is similar to a well-known objection to the use of desert in theories of punishment. See, especially, Dolinko (1991).

${ }^{20}$ For a deeper defence of this view, and an exploration of exceptions to it, see Tadros (2011, 2020).
} 
that result in her posing a threat. I doubt this could be right. Even if threats that arise due to these things ground duties, those duties are not as stringent as those that arise due to threats caused by one's vices. The threats one should be most strongly concerned with are those that are related to one as a person. This is part of the broader idea that one's reasons for action depend on personal connections between oneself and those actions.

Perhaps it might be thought that this would leave open the possibility that one would have just as strong a reason to respond to one's justified threats as to those one is culpable for posing. But this is also not intuitive. The fact that a threat arises from my failings gives me a special reason to regret posing those threats; I regret not only the fact that the threat was posed, which I can rationally do whether my threat is justified or not, but also the action that poses it, which I cannot rationally do in the case of justified threats. The fact that my moral failings result (in a salient way) in threats to others makes those threats personally reflect on me, in a way that I have reason to regret, and averting them takes on personal importance for me as a result.

The significance of the connection between a person and a threat that arises in this way depends on how grave her fault is in posing the threat. And that suggests that the stringency of her duty to avert the threat that she poses depends on her degree of culpability for posing the threat. As the stringency of those duties corresponds to the strength of her right not to be harmed to avert the relevant threats, those who are more gravely culpable for posing threats also have weaker rights not to be harmed to avert those threats than those who are less gravely culpable. And that explains why I ought to harm the more culpable person in Two Pushers and Two Killers.

To sum up, then, culpability affects liability independently of responsibility. Two people who will be equally responsible for a death if they act, but who will not be equally culpable, are not equally liable. The more culpable person has greater liability than the less culpable person.

\section{Conclusion}

A central issue in the philosophy of self-defence and war has concerned the role of responsibility and culpability in making a person liable to defensive harm. However, the literature is still underdeveloped in providing an account of responsibility, culpability, and the relationship between them. Here, I have argued that these two notions are not as closely related as some think. Even though there are some cases where culpability and responsibility go together, there are others where they do not—culpability and responsibility are constituted by some of the same things and by some different things.

This account also has implications for the philosophy of responsibility. It is often assumed that there is a close relationship between responsibility and blameworthiness. Indeed, some think that blameworthiness for some conduct just is responsibility for that conduct, or a kind of responsibility for that conduct. However, at least some facts that make a person more blameworthy for her conduct 
do not make her more responsible for her conduct. More strongly, I have outlined a general idea of responsibility that is not particularly tied to blameworthiness at all.

Furthermore, the degree to which someone is responsible for posing a threat can affect her liability independently of whether this affects her degree of culpability, and the degree to which someone is culpable for posing a threat can affect her liability independently of whether this affects her degree of responsibility.

Acknowledgements School of Law, University of Warwick. I am grateful to the participants at the Conversations on War Workshops organised by the Stockholm Centre for the Ethics of War and Peace and King's College London in Seville and Perast, as well as two anonymous referees

Funding None.

\section{Compliance with ethical standards}

Conflict of interest The author declare that they have no conflict of interest.

Open Access This article is licensed under a Creative Commons Attribution 4.0 International License, which permits use, sharing, adaptation, distribution and reproduction in any medium or format, as long as you give appropriate credit to the original author(s) and the source, provide a link to the Creative Commons licence, and indicate if changes were made. The images or other third party material in this article are included in the article's Creative Commons licence, unless indicated otherwise in a credit line to the material. If material is not included in the article's Creative Commons licence and your intended use is not permitted by statutory regulation or exceeds the permitted use, you will need to obtain permission directly from the copyright holder. To view a copy of this licence, visit http:// creativecommons.org/licenses/by/4.0/.

\section{References}

Beebee, H., \& Kaiserman, A. (forthcoming). Causal contribution in war. Journal of Applied Philosophy Bratman, M. (1999). Intentions, plans and practical reason. USA: CLSI.

Dolinko, D. (1991). Some thoughts about retributivism. Ethics, 101(3), 537-559.

Frowe, H. (2014). Defensive killing. Oxford: OUP.

Gardner, J. (2007). The gist of excuses. Offences and defences: selected essays in the philosophy of criminal law. Oxford: OUP.

Gardner, J. (2007). The mark of responsibility. Offences and defences: selected essays in the philosophy of criminal law. Oxford: OUP.

Gardner, J., \& Tanguay-Renaud, F. (2011). Desert and avoidability in self-defense. Ethics, 122(1), 111-134.

Kagan, S. (2012). The geometry of desert. Oxford: OUP.

McMahan, J. (2005). The basis of moral liability to defensive killing. Philosophical Issues, 15(1), 386-405.

McMahan, J. (2009). Killing in war. Oxford: OUP.

McMahan, J. (2010). Humanitarian intervention, consent, and proportionality. In N. A. Davis, R. Keshen, \& J. McMahan (Eds.), Ethics and humanity: themes from the philosophy of jonathan glover. Oxford: OUP.

Nagel, T. (1986). The view from nowhere. Oxford: OUP.

Parfit, D. (2002). Equality and priority? In M. Clayton \& A. Williams (Eds.), The ideal of equality. Basingstoke: Palgrave.

Parfit, D. (2017). On what matters (Vol. 3). Oxford: OUP.

Quinn, Q. (1993). Actions, intentions, and consequences: The doctrine of double effect. Morality and action. Cambridge: CUP.

Quong, J. (2012). Liability to defensive harm. Philosophy and Public Affairs, 40(1), 45-77. 
Quong, J. (2015). Proportionality, liability, and defensive harm. Philosophy and Public Affairs, 43(2), 144-173.

Quong, J. (2020). The morality of defensive force. Oxford: OUP.

Quong, J., \& Firth, J. (2012). Necessity, moral liability, and defensive harm. Law and Philosophy, 31(6), 673-701.

Sartorio, C. (forthcoming). More of a Cause?. Journal of Applied Philosophy.

Scanlon, T. M. (1998). What we owe to each other. Cambridge, Mass: Harvard UP.

Singer, P. (2010). Bystanders to poverty. In N. A. Davis, R. Keshen, \& J. McMahan (Eds.), Ethics and humanity: themes from the philosophy of jonathan glover. Oxford: OUP.

Sliwa, P. (2019). The power of excuses. Philosophy and Public Affairs, 47(1), 37-71.

Smith, A. M. (2007). On being responsible and holding responsible. Journal of Ethics, 11(4), 465-484.

Stemplowska, Z. (2013). Harmful choices: scanlon and voorhoeve on substantive responsibility. Journal of Moral Philosophy, 10(4), 488-507.

Tadros, V. (2005). Criminal responsibility. Oxford: OUP.

Tadros, V. (2011). The ends of harm: the moral foundations of criminal law. Oxford: OUP.

Tadros, V. (2016). Causation, culpability, and liability. In C. Coons \& M. Weber (Eds.), The ethics of self-defense. Oxford: OUP.

Tadros, V. (2018). Causal contributions and liability. Ethics, 128(2), 402-431.

Tadros, V. (2020). To do, to die, to reason why: individual ethics in war. Oxford: OUP.

Wallace, R. J. (1994). Responsibility and the moral sentiments. Cambridge, Mass: Harvard UP.

Williams, A. (2007). Liberty, liability, and contractualism. In N. Holtug \& K. Lippert-Rasmussen (Eds.), Egalitarianism: new essays on the nature and value of equality. Oxford: OUP.

Publisher's Note Springer Nature remains neutral with regard to jurisdictional claims in published maps and institutional affiliations. 